\title{
Comparison Essential Oil Contents Origanum majorana L. Obtained by Hydrodistillation and SFE
}

\section{Hidrodistilasyon ve SFE Kullanarak Elde Edilen Origanum majorana L.'nin Uçucu Yağ Bileşiminin Karşılaştırılması}

\section{Ezgi Aytaç ${ }^{\odot}$}

Department of Plant Sciences, Faculty of Agriculture and Natural Sciences, Konya Food and Agriculture University, Konya, Turkey.

\section{ABSTRACT}

T

he volatile components of Origanum majorana L. essential oil obtained from both hydrodistillation and supercritical fluid extraction (SFE) were determined by GC-MS and GC-FID. Extraction of these biologically active compounds requires the usage of large amounts of environmentally unfriendly solvents and technologies operating with high costs. Supercritical fluid extraction is an environmentally friendly and efficient extraction technique for solid materials, being extensively studied for the separation of active compounds from herbs and other plants. The essential oil obtained by SFE contains mainly carvacrol (76.69\% with GC-MS and 91.95\% with GC-FID) which are responsible for the characteristic flavour and fragrance of marjoram oil. And also to compare with SFE, the essential oil obtained by hydrodistillation contains mainly carvacrol $(70.47 \%$ with GC-MS and $89.00 \%$ with GC-FID). It can be concluded that almost all the biologically active compounds from marjoram herb can be efficiently extracted by SFE.

\section{Key Words}

Origanum majorana L., SFE, hydrodistillation, essential oil

\section{öz}

$\mathrm{O}$ iganum majorana L'nin hem hidrodistilasyon hem de süperkritik akışkan ekstraksiyonu (SFE) ile elde edilen uçuğu yağ bileşimi GC-MS ve GC-FID ile belirlendi. Biyolojik aktif bileşenlerin ekstraksiyonu çevreye zarar veren çözücülerin aşırı kullanımını ve çok yüksek ücretli teknolojileri gerektirir. Süperkritik akışkan ekstraksiyonu şifalı bitkiler ve diğer bitkilerden aktif bileşenlerin ayrılması için yoğunlukla çalışılan katı materyaller için çevreye dost ve etkili bir ekstraksiyon tekniğidir. SFE'den elde edilen uçucu yağın yüksek oranda marjoram yağının tadından ve karakteristik kokusundan sorumlu olan karvakrolü (76.69\% GC-MS ve 91.95\% GC-FID) içerdiği tespit edildi. SFE ile karşılaştırıldığında hidrodistilasyon ile elde edilen uçucu yağlar da yüksek oranda karvakrol (70.47\% GC-MS ve $89.00 \%$ GC-FID) içerir. Buradan çıkarılacak sonuç; marjoram bitkisinden elde edilen biyolojik aktif bileşenler SFE ile verimli bir şekilde ekstrakte edilebilir.

\section{Anahtar Kelimeler}

Origanum majorana L., SFE, hidrodistilasyon, uçucu yağ

Article History: Received: Jan 17, 2019; Revised Jun, 23 2019; Accepted: Jan 29, 2020; Available Online: May 3, 2020.

DOI: https://doi.org/10.15671/hibc.514042

Correspondence to: E. Aytaç, Department of Plant Sciences, Konya Food and Agriculture University, Konya, Turkey.

E-Mail: ezgi.aytac@gidatarim.edu.tr 


\section{INTRODUCTION}

$\mathrm{M}$ any medicinal plants are known to contain large amounts of antioxidants which can play an important role in scavenging free radicals and reactive oxygen species. Because of the drugs stresses, toxic substances, or diseases, the production of active oxygen species increases, which has the potential to cause oxidative damage [1]. Antioxidants have vital functions in avoiding oxidative mechanisms that cause to degenerative diseases [2]. Nowadays, free radicals show important functions in the etiology of cardiovascular diseases, such as cancer, Alzheimer, and Parkinson [3]. Evidence shows that the vegetable and fruit consumption decreases the risk of several pathological events, such as cancer and cardio- and cerebro vascular diseases [4]. Additionally, plants or their crude extracts have been used in the prevention and/or treatment of some diseases around the world [5].

Essential oils (EO) a group of plant derived secondary metabolites have well known antioxidant properties, which can be characterized directly via interaction with peroxyl radicals. Essential oils are aromatic oily liquids extracted from different parts of plants (leaves, seeds, roots, fruits, etc.) either by hydrodistillation or solvent extraction [6]. These natural products have got increasing attention in the chemical, food and pharmaceutical industries, because they can have a wide range of activities and good candidates to replace several synthetic compounds [7].

The volatile oils can be obtained by different processes, depending on the location of the plant, the amount and the characteristics required for the final product. These are the number of methods such as steam distillation (SD), hydrodistillation (HD), organic solvent extraction, microwave assisted distillation (MAD), microwave hydrodiffusion and gravity (MHG), high pressure solvent extraction (HPSE), supercritical fluid extraction (SFE), ultrasonic extraction (UE) and solvent free microwave extraction (SFME). However, the properties of the essential oils extracted through these methods have been found to vary depending on the method used [8]. The conventional techniques are pressing extraction with organic solvents (for delicate raw materials, as flowers petals), hydrodistillation (a common method, used for the extraction of volatile from aerial parts of plants) and extraction with supercritical fluids (interest in determined fraction of oil) and distillation (heat resistant substances) [9]. The alteration caused by hydrodistillation is remarkable as plant material in contact with steam undergoes many chemical changes. Hot steam will decompose many aldehydes and esters. Some water-soluble molecules may be lost by solution in the water, thus altering the chemical profile of the oil [9]. Supercritical fluid solvents such as $\mathrm{SC}-\mathrm{CO}_{2}$ are intermediates between liquid and gases and considered important in the separation processes based on the physicochemical characteristics including density, viscosity, diffusivity and dielectric constant which are easily manipulated by pressure and temperature. It also has a critical temperature $(\mathrm{Tc}=304.1 \mathrm{~K})$ that makes it suitable for the extraction of many natural products under mild conditions [9].

The mint family (Lamiaceae) includes aromatic plants widely used for culinary, medicinal, cosmetic and ornamental purposes, such as basil, rosemary, sage, oregano, lavender, thyme and mint [10]. Origanum spp. belongs to the Lamiaceae family, which consists of 49 taxa, subdivided to 10 sections, its species widely distributed in Eurasia and North Africa [11] being native to the mountainous areas of Mediterranean and Asia [12]. Species belonging to the genus Origanum are used since the ancient times as spices, medicinal, aromatic and ornamental plants [13]. In vitro pharmacological investigations showed their antibacterial, antifungal, antioxidant, antispasmodic, antimutagenic, antitumoral, analgesic, antithrombin and antihyperglycaemic activities [12].

Origanum majorana is a culinary herb and is called as "sweet marjoram" because of its citrus flavours. Additionally, Turkey has become a major supplier of Origanum herb and its oil to world markets due to its high quality. The fresh or dried highly aromatic leaves and flowering tops of sweet marjoram are widely used adding flavor to many foods. Its essential oil and alcoholic extracts have versatile applications in pharmaceuticals, perfumes and cosmetics. The essential oil of sweet marjoram from different origins was previously analyzed for the composition and biological activities [14]. Lamiaceae plants are collected from the wild or grown as commercial crops and used to prepare many commercial products, including herbal teas, spices, beverages, pharmaceutical products [15].Current data shows that the essential oils of origanum species are rich sources of active compounds with particular biological importance, known for its antibacterial and antifungal activities [16]. 
The objective of this work was to evaluate and compare the chemical profile of essential oils of marjoram (Origanum majorana L.) from the Mediterranean region of Turkey obtained by hydrodistillation (Clevenger apparatus) and supercritical $\mathrm{CO}_{2}$. Because, the qualitative and quantitative changes in chemical compounds by using SFE compared with hydrodistillation are poorly studied.

\section{MATERIALS and METHODS}

\section{Plant Material}

Origanum majorana L. plants (about $1 \mathrm{~kg}$ ) were collected from Akseki, Antalya which obtained from Alanya General Directorate of Forestry in June, 2017. Samples were allowed to dry in the shade. Seeds obtained from ripened fruits were separated from the plant material, and collected in a separate bag before storing at $6^{\circ} \mathrm{C}$ in a refrigerator until analysis. The seeds were ground in a using a mechanical mill. The dried, finely ground sweet marjoram sample was a greyish-brown fine powder with a characteristic scent. This powder was used for all the extractions.

\section{Hydrodistillation Procedure (Clevenger Aparatus)}

$100 \mathrm{~g}$ of Origanum majorana L. was used for hydrodistillation extracting system. The essential oil was extracted over a period of 90 min using a Clevenger apparatus and the yield of oil was recorded at every $5 \mathrm{~min}$. After hydrodistillation, water was removed by decantation and the essential oil obtained was stored at $4^{\circ} \mathrm{C}$ in a dark-colored container to prevent light-sensitive decomposition.

\section{Supercritical Fluid Extraction (SFE) Procedure}

Supercritical $\mathrm{CO}_{2}$ extraction is the best green extraction method to remove nonpolar components such as seed oils [17]. If supercritical fluid contains polar solvents such as methanol, ethanol or water more polar compounds can be extracted. Applied Separation supercritical extractor (Spe-ed SFE) equipped with a modifier pump (Applied Seperation Series 1500), pressure pump (Atlas Copco GX-4FF) and chiller (Applied Seperation Polyscience) was used for all the extractions. The system run for 30 min under following conditions:

Sample mass: $100 \mathrm{~g}$

Temperature: $40^{\circ} \mathrm{C}$

$\mathrm{CO}_{2}$ flow rate: $7 \mathrm{~kg} / \mathrm{h}$

Pressure: 150 bar

Vessel volume: $0.50 \mathrm{~L}$

\section{Chemical Characterization (GC-MS and GC-FID Analyses)}

The quantification of essential oil components was performed by gas chromatography (GC) in equipment Shimadzu GC-210. The analyses were carried out using a capillary column RESTEK, Rxi-5 Sil MS 30 Meter 0.25 mm ID $0.25 \mu \mathrm{m} \mathrm{df}$, detector FID, following the temperature program: $40-180^{\circ} \mathrm{C}\left(3^{\circ} \mathrm{C} \mathrm{min}-1\right), 180-240^{\circ} \mathrm{C}\left(20^{\circ} \mathrm{C} \mathrm{min}-1\right)$, $240^{\circ} \mathrm{C}$ (20 min), temperature of injector $250^{\circ} \mathrm{C}$, injection mode split, carrier gas $\mathrm{He}$, injection volume of $0.4 \mu \mathrm{L}$ (sample diluted in $\mathrm{n}$-hexane 1:10).

The determination of chemical profile of essential oil components was carried out in a gas chromatography with mass spectrometer as detector (GC-MS), model Shimadzu GC $17 \mathrm{~A}$, ion source temp: $200^{\circ} \mathrm{C}$, interface temp: $250^{\circ} \mathrm{C}$, solvent cut time: $4 \mathrm{~min}$. Chromatographic patterns as thymol, sabinene hydrate, $\alpha$-terpinene and $\gamma$-terpinene (Fluka) and $\alpha$-terpineol, camphene, 4-carvomenthenol, limonene, $\alpha$-pinene, carvacrol, $\beta$-pinene, myrcene, $\mathrm{p}$-cimene, limonene, 1,8-cineol, terpinolene and linalool (Sigma-Aldrich) were used to the chemical characterization of essential oils.

\section{RESULTS and DISCUSSION}

The mean yield of essential oils of marjoram obtained by Clevenger apparatus $4.2 \pm 0.23 \mathrm{~g}$ per $100 \mathrm{~g}$ of leaf. The values four times higher than that found by Busatta et al [18]. The mean yield obtained by the supercritical fluid extraction was $4.5 \pm 0.32 \mathrm{~g}$ per $100 \mathrm{~g}$ leaf and also it is 2.5 times higher than obtained by Busatta et al [18].

However, the quality and activity of extract is greatly dependent upon the process. Hydrodistillation (HD) with Clevenger aparatus and solvent extraction have been the major processes for a long time. During last decades, the use of supercritical fluids for extraction of plant volatile fraction has been increasingly preferred [19]. This is due to the advantages of the supercritical fluid extraction technique: rapid, selective, and convenient technique for extraction of natural compounds from aromatic and medicinal plants. Also, SFE extracts are considered as solvent free, which enhances their attractiveness for the consumer [20]. For instance, the color intensity of the extracts from both species was different, the Clevenger extracts were yellow, and the extracts by SFE exhibited a dark yellow color that can be attributed to the differences in chemical composition. This is probably due to the properties of SFE technique 
including the low temperature and rapidity $\left(40^{\circ} \mathrm{C}, 30\right.$ min), which minimize the high temperature exposure and consequently the lower thermal degradation than Clevenger (around $100^{\circ} \mathrm{C}, 90 \mathrm{~min}$ ) [21].

Due to their structural relationship within the same chemical group, essential oil components are known to easily convert into each other by oxidation, isomerization, cyclization, or dehydrogenation reactions, triggered either enzymatically or chemically. Upon stability evaluation of essential oils, it needs to be kept in mind that the chemical composition may already vary in the starting material, being influenced by plant health, growth stage, habitat including climate, edaphic factors, as well as harvest time [22].

As terpenoids tend to be both volatile and thermolabile and may be easily oxidized or hydrolyzed depending on their respective structure [23], it is well accepted that the chemical composition of essential oils is moreover dependent on the conditions during processing and storage of the plant material, upon distillation as well as in the course of subsequent handling of the oil itself [24].

The results are in complete agreement with the literature $[25,26]$, as both hydrodistillation and supercritical $\mathrm{CO}_{2}$ extraction techniques produce almost the same main volatile compounds but with negligible monoterpene hydrocarbons for the second case. According to Temelli et al. [27] an attractive point of supercritical extraction is to obtain extracts rich in aroma compounds with the lowest possible monoterpene concentration, because they do not contribute much to the flavor of essential oils and also because they are very sensitive to heat and light and may decompose into undesirable substances [28].

In the literature, in the most cases, the comparison between hydrodistillation (HD) with Clevenger aparatus and SFE extraction showed a difference of yields but a few variations in chemical composition for the same major compounds in the extract. SFE extracts from marjoram were characterized by higher contents of heavier molecular weight compounds (retention time in the range 30 to $40 \mathrm{~min}$ ) than in the case of the HD essential oils. In parallel, lighter components, for example, alpha-thujene, alpha-pinene, and gamma-terpinene, present in the HD essential oils, were weakly detected in the SFE extracts. This does not mean that such light compounds are not present in SFE extracts, but the pre- sence of other compounds, especially heavy ones, will make these compounds in trace quantity. Indeed, it would be surprising that SFE does not extract such kind of lighter compounds, which are known for being soluble in $\mathrm{CO}_{2}$ in these conditions.

The chromatographic analysis permitted the identification of carvacrol as the most prominent compounds present in the cultivated Origanum majorana L. with hydrodistillation and the SFE. Results (Table 1.) showed an important difference in monoterpene and sesquiterpenes (hydrocarbons and oxygenated) identified in each extract. Indeed, the sesquiterpenes were much better extracted by SFE than hydrodistillation. The opposite was noted for the monoterpenes: $11.49 \%$ (with GC-MS) in hydrodistillation compared to $3.84 \%$ (with GC-MS).

The extraction method influenced significantly the chemical composition of the extracts. The concentration of phenols increased from approximately 70 to 77 with GC-MS from hydrodistillation to SFE and also with GCFID increased from approximately 89 to 92 with SFE in comparison to hydrodistillation. The major compound of marjoram essential oil obtained with SFE and hydrodistillation carvacrol, followed by $\delta$-terpinene, myrcene and $\alpha$-terpinene (Table 1.).

Some major compounds as $\alpha$-terpinene, $\delta$-terpinene and myrcene were found in the essential oils from hydrodistillation compared to those from SFE. A four times higher concentration of $\delta$-terpinene and two times higher concentration of myrcene was obtained for both oils obtained by hydrodistillation with Clevenger apparatus.

So, the present works show the occurrence of qualitative differences on the essential oils, related to the extraction method (SFE and Hydrodistillation). A higher extraction capacity of phenols by SFE, allowing optimizing the extraction of compounds of interest by the choice of the most adequate extraction method was observed. According to these characteristic features Origanum majorana L. oil can be classified as valuable oil for human nutrition. 
Table 1. Chemical composition of the essential oil from Origanum majorana L. obtained by hydrodistillation and SFE.

\begin{tabular}{|c|c|c|c|c|c|}
\hline & \multirow{3}{*}{ Compound Name } & \multicolumn{2}{|c|}{ Hydrodistillation } & \multicolumn{2}{|c|}{ SFE } \\
\hline & & MS (\%) & FID (\%) & MS (\%) & FID (\%) \\
\hline & & \multicolumn{4}{|c|}{ Monoterpene Hydrocarbons } \\
\hline 1 & $\alpha$-Thujene & 1.25 & 0.64 & - & - \\
\hline 2 & $\alpha$-Pinene & 0.96 & 0.51 & 0.37 & 0.19 \\
\hline 3 & Sabinene & - & - & - & - \\
\hline 4 & $\beta$-Pinene & 0.29 & 0.12 & - & - \\
\hline 5 & Myrcene & 2.29 & 1.17 & 0.69 & 0.33 \\
\hline 6 & $\alpha$-Phellandrene & 0.31 & 0.12 & 0.16 & 0.05 \\
\hline 7 & $\alpha$-Terpinene & 1.48 & 0.63 & 1.10 & 0.48 \\
\hline 8 & Limonene & - & - & - & - \\
\hline 9 & p-Cymene & - & - & - & - \\
\hline 10 & $\nu$-Terpinene & 4.56 & 2.47 & 1.36 & 0.64 \\
\hline \multirow[t]{3}{*}{11} & Terpinolene & 0.35 & 0.08 & 0.16 & 0.06 \\
\hline & Total & 11.49 & 5.74 & 3.84 & 1.75 \\
\hline & & \multicolumn{4}{|c|}{ Oxygenated Monoterpenes } \\
\hline 12 & 1,8-Cineole & - & - & 0.41 & 0.05 \\
\hline 13 & trans-Sabinene hydrate & 0.60 & 0.22 & - & - \\
\hline 14 & cis-Sabinene hydrate & - & - & - & - \\
\hline 15 & Linalool & 0.33 & 0.01 & 0.37 & 0.14 \\
\hline 16 & trans-p-Menth-2-enol & - & - & - & - \\
\hline 17 & cis-p-Menth-2-enol & - & - & - & - \\
\hline 18 & Terpinen-4-ol & - & - & - & - \\
\hline 19 & $\alpha$-Terpineol & 0.76 & 0.01 & - & - \\
\hline 20 & trans-Piperitol & - & - & - & - \\
\hline 21 & cis-Piperitol & - & - & - & - \\
\hline 22 & Geraniol & - & - & - & - \\
\hline \multirow[t]{3}{*}{23} & Linalyl acetate & - & - & - & - \\
\hline & Total & 1.69 & 0.24 & 0.78 & 0.19 \\
\hline & & \multicolumn{4}{|c|}{ Phenols } \\
\hline 24 & Thymol & - & - & - & - \\
\hline \multirow[t]{3}{*}{25} & Carvacrol & 70.47 & 89.00 & 76.70 & 91.95 \\
\hline & Total & 70.47 & 89.00 & 76.70 & 91.95 \\
\hline & & \multicolumn{4}{|c|}{ Sesquiterpene Hydrocarbons } \\
\hline 26 & $\beta$-Caryophyllene & 1.34 & 0.43 & 1.35 & 0.47 \\
\hline \multirow[t]{3}{*}{27} & Germacrene & - & - & - & - \\
\hline & Total & 1.34 & 0.43 & 1.35 & 0.47 \\
\hline & & \multicolumn{4}{|c|}{ Oxygenated Sesquiterpenes } \\
\hline 28 & Caryophyllene oxide & - & - & 0.62 & 0.19 \\
\hline \multirow[t]{3}{*}{29} & Spathulenol & - & - & - & - \\
\hline & Total & - & - & 0.62 & 0.19 \\
\hline & Total Identified Compounds & 84.99 & 95.41 & 83.29 & 94.55 \\
\hline
\end{tabular}




\section{Acknowledgement}

Thanks to Prof. Atalay Sokmen from Konya Food and Agriculture University for plant supply and identification.

\section{References}

1. B. Frei, Natural antioxidants in human health and disease, Free Rad. Biol. Medic., 20 (1996) 157-159.

2. A. Cardador-Martinez, G. Loacra-Pina, B.D. Oomah, Antioxidant activity in common beans (Phaseolus vulgaris L.), J. Agri. Food Chem., 50 (2002) 6975-6980.

3. V.N. Enujiugha, J.Y. Talabi, S.A. Malomo, A.L. Olagunju, DPPH radical scavenging capacity of phenolic extracts from african yam bean (Sphenostylis stenocarpa), Food Nutrit. Sci., 3 (2012) 7-13.

4. E.B. Rimm, A. Ascherio, E. Giovannucci, D. Spiegelman, M.J. Stampfer, W.C. Willett, Vegetable, fruit and cereal fiber intake and risk of coronary heart disease among men, J. Amer. Medic. Ass., 275 (1996) 447-451.

5. G. Semiz, A. Semiz, N. Mercan-Doğan, Essential oil composition, total phenolic content, antioxidant and antibiofilm activities of four Origanum species from southeastern Turkey, Int. J. Food Proper., 21 (2018) 194-204.

6. G.B. Salha, R.H. Diaz, J. Labidi, M. Abderrabba, Deterpenation of Origanum majorana L. essential oil by reduced pressure steam distillation, Indust. Crops Prod., 109 (2017) 116-122.

7. A. Cháfer, J. Torre, R. Muñoz, M.C. Burguet, Liquid-liquid equlibria of the mixture linalool + ethanol + water at different temperatures, Fluid Phase Equilibria, 238 (2005) 72-76.

8. O.O. Okoh, A.P. Sadimenko, A.J. Afolayan, Comparative evaluation of the antibacterial activities of the essential oils of Rosmarinus officinalis L. obtained by hydrodistillation and solvent free microwave extraction methods, Food Chem. 120 (2010) 308-312.

9. C. Busattaa, J. Barbosaa, R. I.Cardosoa, N. Paroula, M. Rodriguesb, D. Oliveirac, J.V. Oliveirac, R.L. Cansiana, Chemical profiles of essential oils of marjoram (Origanum majorana) and oregano (Origanum vulgare) obtained by hydrodistillation and supercritical $\mathrm{CO}_{2}$, J. Essent. Oil Res., 29 (2017) 367-374

10. R. Raja, Medicinally potential plants of Labiatae (Lamiaceae) family: An overview, J. Res. Plants Med. 6 (2012) 203-213.

11. J.H. letswaart, A taxonomic revision of the genus Origanum (Labiatae), Leiden Botanical series, Leiden University Press, 4 (1980)

12. S. Chishti, Z.A. Kaloo, P. Sultan, Medical importance of genus Origanum: A review, J. Pharmacognosy Phytother. 5 (2013) 170-177.

13. M. Meyers, Oregano and Marjoram, The Herb Society of America, Guide to the genus Origanum, The Herb Society of America, Kirtland, Ohio, 2005.

14. B. Teixeira, A. Maryues, C. Ramos, C. Serrano, O. Matos, N.R. Neng, J.M. Noqueira, J.A. Saraiva, M.L. Nunes, Chemical composition and bioactivity of different oregano (Origanum vulgare) extracts and essentail oil, J. Sci. Food Agric, 93 (2013) 2707-2714.
15. C.M. Asensio, N.R. Grosso, H.R. Juliani, Quality characters, chemical composition and biological activities of oregano (Origanum spp.) Essential oils from Central and Southern Argentina, Ind. Crop. Prod. 63 (2015) 203-221.

16. O. Baâtour, I. Tarchoun, N. Nasri, R. Kaddour, J. Harrathi, E. Drawi, M. Ben Nasri- Ayachi, B. Marzouk, M. Lachaâl, Effect of growth stages on phenolics content and antioxidant activities of shoots in sweet marjoram (Origanum majorana L.) varieties under salt stress, Afr. J. Biotechnol., 11 (2012) 16486-16493.

17. F. Chemat, M.A. Vian, G. Cravotto, Green extraction of natural products: concept and principles, Int. J. Molecul. Sci., 13 (2012) 8615-8627.

18. S.M. Pourmortazavi, S.S. Hajimirsadeghil Supercritical fluid extraction in plant essential and volatile oil analysis, J. Chromatogr. A, 1163 (2007) 2-24.

19. B. Berka-Zougali, M.A. Ferhat, A. Hassani, F. Chemat, K.S. Allaf, Comparative study of essential oils extracted from Algerian Myrtus communis L. leaves using microwaves and hydrodistillation. Int. J. Mol. Sci., 13 (2012) 4673-95.

20. Y. Yamini, F. Sefidkon, S.M. Pourmortazavi, Comparison of essential oil composition of Iranian fennel (Foeniculum vulgare) obtained by supercritical carbon dioxide extraction and hydrodistillation methods, Flav. Fragr. J., 17 (2002) 3458

21. A.C. Figueiredo, J.G. Barroso, L.G. Pedro, J.J.C. Scheffer, Factors affecting secondary metabolite production in plants: Volatile components and essential oils, Flav. Fragr. J., 23 (2008) 213-226.

22. C. Turek, F.C. Stintzing, Stability of Essential Oils: A review, Comprehensive Reviews in Food Science and Food Safety, Vol 12, 2013

23. B. Simandi, M. Ozszagyan, E.A. Lemberkovics, A.A. Kery, J. Kaszacs, F. Thyrion, T. Matyas, Supercritical carbon dioxide extraction and fractionation of oregano oleoresin, Food Res. Int., 31 (1998) 723-728.

24. R.P.W. Scott, Essential oils, Encyclopedia of analytical science. 2nd ed. Amsterdam, London, New York: Elsevier (2005) 554-61.

25. M. Ordaza, A. Sanchez, Steam distillation and supercritical fluid extraction of some Mexican spices, Chromatographia, 30 (1990) 16-18.

26. F. Temelli, R.J. Braddock, C.S. Chen, Nagy, Supercritical carbon dioxide extraction of terpenes from orange essential oil In: Supercritical fluid extraction and chromatography: Techniques and applications; B.A. Charpentier, R. Sevenants, Eds.; ACS Symposium Series 366; American Chemical Society, Washington, DC, 1988; p 109

27. M.R.A. Rodrigues, L.C. Krause, E.B. Caramoa, J.G. Santos, C. Dariva, J.V. Oliveira, Chemical composition and extraction yield of the extract of origanum vulgare obtained from suband supercritical $\mathrm{CO}_{2}$, J. Agricult. Food Chem., 52 (2004) 3042-3047.

28. M. Sharifi-Rad, E.M. Varoni, M. Iriti, M. Martorell, W.N. Setzer, M.M. Contreras, B. Salehi, A.S. Nejad, S. Rajabi, M. Tajbakhsh, J. Sharifi-Rad, Carvacrol and human health: A comprehensive review, Phytother. Res., 32 (2018) 16751687. 